\title{
New Poetry Section - Call for Submissions
}

\section{新诗歌专栏-征稿}

\author{
Stephen K. Levine \\ The European Graduate School, Switzerland
}

CAET is excited to announce a new poetry section in the journal. Poetry has been an important part of Chinese and other Asian cultures since their very inception and Chinese poetry has been the source of inspiration for many poets and novelists who write in other languages. English-language poets, in particular, have used Chinese themes and forms as points of inspiration for their own work. We invite submissions of poems - accompanied by each poet's artist statement - for future issues. Poems should be in English, Chinese or other languages (accompanied by good English translations).

CAET很高兴在期刊发布一个新的诗歌板块。自从诗歌这种文体的出现， 它一直是中国和其他亚洲文化的重要组成部分。中国诗歌一直是用其他语言写 作的许多诗人和小说家灵感源泉，尤其是英文诗人，用中国的主题和形式作为 自己作品的灵感。我们将在今后的期刊中邀请诗歌作品 并附上每位诗人的艺术 家声明。诗歌应以英文，中文或其他语言（配有良好的英文翻译）。

In this issue, we feature the work of James P. Lenfestey, a contemporary American poet who was intrigued and inspired by the work of T'ang poet Han-shan (also known as Cold Mountain) in the English-language translations by Burton Watson. The following is an account of Lenfestey's excitement on reading Han-Shan and the subsequent inspiration he took from this work to create his own poetic responses:

"I opened my grocery bag full of accumulated research and spread the contents around me on the floor. I happened upon a book I'd forgotten I'd brought with me, my much-worn copy of Cold Mountain poems by Han-shan.

Han-shan! Brother!

Twenty-two years ago I came upon Han-shan's one hundred Cold Mountain poems translated by Burton Watson. A friend gave me the book just prior to a long retreat with fellow staff members from the school where I worked. As we drove in the van I read the poems out loud. We all laughed until we were weak. Han-shan's personal laments, witty observations and broad insights, all in accessible conversational speech, sounded as familiar to me as if written by an older brother. Yet Han-shan lived, if he lived at all and isn't a literary fiction, more than a thousand years ago on the coast of China. Once a family man and government worker, he spent the end of his life a hermit, meditating and laughing out loud on the wild slopes of Cold Mountain, inscribing his few poems on rocks and trees.

As the school car rolled on in silence, I began to write my own responses to Hanshan's voice. Twenty years later, I am still writing to him. 
I put down the essay and read Watson's translation numbered 39:

'The birds and their chatter overwhelm me with feeling:

At times like this I lie down in my straw hut.

Cherries shine with crimson fire.

Willows trail slender boughs.

The morning sun pops from the jaws of blue peaks;

Bright clouds are washed in the green pond.

Who ever thought I would leave the dusty world and come bounding up the southern slope of Cold Mountain?'

As I finished reading, the pileated woodpecker I had chased that morning landed on a birch right next to my window. As he worked around that fat trunk alone in the cedars, I watched in a hush. When he flew away, I wrote the following poem from the slope of my own Cold Mountain:

When sound leaks from a cedar grove, better listen!

When moss falls by the window pane, better sit up.

A woodpecker big as a hatchet taps out

his elusive forest story right in front of me!

I lean back breathless from my desk,

forgetting for a moment the chair is broken.

Who would have thought I'd find a place so quiet

that what is longed for flies right in?

So that's what I'd been seeking all week, a time quiet enough for feelings to flow, a space open enough for what arrives. That is the moment when poets write not what comes to our minds but what comes out our fingers through pencils or typewriters or laptop computers, a direct connection to the soul through touch.

And the classical Chinese shih form of four or eight lines (more or less) offers those feelings a sturdy container, a place to rest, a home. It asks for quotidian detail, which easily orients the reader/writer - where are we right now? - and a "leap," as Robert Bly famously called it, the "turn" in classical Chinese, often in the final couplet, darting toward the other world, tzu-jan, "self-ablaze."

All of this slowly dawned on me, low morning sun spreading over a field of winter wheat, as over the decades I read and memorized Cold Mountain, then the many others who became not just poets, but friends. Some were monks, some administrators in the court, some exiles, some landed lords. A few were able to shed the husk of this world, but most lived in the space between the lightness of tzu-jan and the heaviness of responsibilities to family, career, the earth herself. That tension, that longing, is where I live too."

(Reprinted from The Urban Coyote: Howlings on Family, Community and the Search for Peace and Quiet (Nodin Press, C2000, used by permission.) 
James P. Lenfestey was also kind enough to send us some poems for the CAET Journal; these are written in the style of Chinese Shih-poetry:

\section{DAWN}

If there were a God, this is how his play would open principal characters asleep, audience awake and restless.

The house moon and morning stars fade to black, audience eager to touch the first designs of morning light.

Enter the chorus of dawn birds as human dreams fade.

Then the conflict begins-

The Long March, Thermopylae, Baghdad, Verdun.

\section{A NEARLY FULL MOON}

A nearly-full moon hangs over the ridge like a lamp.

I wait for the rounder thing, the sad pale perfect

female over her high-necked velvet cloak.

But when the coyotes sing to her at seven,

when they spill their chorus of soprano yips and yawps

like moonlight silvering the sad dimensions,

I flow off toward the sea laying my blanket down.

\section{ESTATES}

I gawk at the entrances to large estates.

Past wrought iron set in stone, locked gate,

lane meandering through ranks of live oaks or palms.

Past the emerald pool to fluted columns raising a wide porch,

front door painted dark green, polished brass knocker.

Whomever opens that door, the girl emerging in her pinafore,

I always loved her. And she, without shame, loved me.

\section{SPRING}

Outside, the great siege of winter lifts

into an army of slender grass.

What will I do today to lift the greening world?

Outside, the moan of winter fills with trilling birdsong.

Will I hear today the song of my desire?

Well-rested, the trees splash seeds an inch thick

over driveways, dance in wind on outdoor tables. 
For what joy will my desire fill the air, my roots tremble with wet warm light?

\section{SONGS}

Some goofy bird gulping in the forest sends me reeling through the window to the other world.

The one that sings because it has no choice.

The one where lust transforms the body to a sheen

of green and swaying feathers full of eyes, the key that unlocks the secret hidden in a pair of thighs, and holds a plot of earth against all comers.

And, at season's end, sings for its own heart's sake.

Or, like the crows, warns of a silent, taloned, bloody thing.

\section{HOW I LATE LEARNED GRATITUDE}

I failed utterly to see it standing next to me, to hear it when it whispered my name.

So when she died suddenly, I who loved her fell into darkness thick as the woods a child's lost in. In my dream I carry her wheelchair over the threshold of the hotel she loved in the city she loved. I listen with pleasure as she talks excitedly to the many familiar ghosts strolling the plaza.

\section{WHO CAN SLEEP?}

When the moonlit face in the mirror is your own.

When the light of the printer, the cell phone, the laptop are stars.

When the failing battery in the phone is a living voice.

When the music of the night itself wakes you singing.

\section{FAILURE}

Only ancient poets speak honestly

this word men cannot say.

A new definition, painful, coins itself

every day, year, decade.

Until, some time before death, 
the dark wings of the bird turn white.

Its song becomes almost lovely,

its beauty no longer terrible.

\section{POEM FOUND IN AN ENVELOPE KEPT IN ARTHUR WALEY'S 1940 "TRANSLATIONS FROM THE CHINESE," WHICH I BOUGHT USED}

On the envelope: "To Eleanor."

On the card inside:

"Merry Christmas, Sweetheart.

Sweetheart of mine - I love you

So warmly and sincerely,

Tenderly and thankfully,

Constantly and dearly!

Deeply and devotedly,

Truly and unceasingly-

Yes, I love you, sweetheart mine,

Every day increasingly!"

Signed, "Charles."

On Eleanor's bookplate:

"The poetry of earth is never dead."

James P. Lenfestey is a former editorial writer for the StarTribune in Minneapolis. Since 2000, he has published a collection of personal essays, five collections of poems, edited two poetry anthologies and co-edited Robert Bly in This World. His haibun memoirSeeking the Cave: A Pilgrimage to Cold Mountain - was a finalist for the 2014 Minnesota Book Award. A Marriage Book - a collection of poetry from 50 years of marriage - will be published in December 2017 by Milkweed Editions.

For more information cf. www.coyotepoet.com

\section{About the author}

Stephen K. Levine, Ph. D., D.S.Sc., REAT, Dean of the Doctoral Program in Expressive Arts in the Division of Arts, Health and Society at The European Graduate School (Switzerland), Professor Emeritus at York University (Toronto). Email: stephen.levine@, egs.edu 